\title{
Dental enamel: qualitative evaluation of the surface after application of aluminum oxide (microetching) using the scanning electron microscope
}

\section{Esmalte dental: avaliação qualitativa da superfície tratada com jato de óxido de alumínio ("microetching") por meio de microscopia eletrônica de varredura}

Paulo César Gomes SILVA*

Mariane GONÇALVES**

Tomio NONAKA***

Dionísio VINHA****

SILVA, P. C. G.; GONÇALVES, M.; NONAKA, T.; VINHA, D. Dental enamel: qualitative evaluation of the surface after application of aluminum oxide (microetching) using the scanning electron microscope. Pesqui Odontol Bras, v. 14 , n. 4 , p. 334-339, out./dez. 2000.

\begin{abstract}
Dentistry nowadays can count on a wide range of resources to treat patients. With the development of adhesive materials and several newly introduced restorative techniques, the dental structure can be subjected to different sorts of surface treatment. The use of aluminum oxide flow at high speed to remove dental structure was described by Black in 1945 , however, the literature regarding the use of aluminum oxide jet is still scarce, as far as the alterations occurring in the dental structure are concerned. At the present, with the development of new abrasive air equipment, microabrasion has been added to several adhesive restorative techniques, in the preparation of the dental surface and of inner surfaces of indirect restorations, which will receive the application of adhesive materials. The aim of this study was to assess the alterations produced by abrasive air applied on the dental enamel by means of electronic microscopy, taking into consideration micromorphological surface alterations. The importance of this study is based on the fact that alternative surface treatments both chemical and mechanical could be introduced in surface priming, including dental enamel priming.
\end{abstract}

UNITERMS: Dental enamel; Aluminum oxide; Scanning electron microscopy.

\section{INTRODUCTION}

Modern time dentistry counts on several resources for treating patients concerning both restorative materials and dental restorative techniques, as well as equipment for dental use. Such fact is the result of the researchers' restless search for knowledge to develop functional, esthetic and long lasting dental restorations.

Buonocore introduced the concept of acid etch of the dental surface in 1955 - a concept which took about two decades to be fully accepted. Through a research conducted by SILVERSTONE et l. $^{20}$ in 1975 , it was possible to observe, by means of scanning electron microscopic analysis, the morphological alterations which occurred in the dental enamel after treatment using phosphoric acid, and they where classified in patterns type I, II and III.

Nowadays, with the development of adhesive materials and the introduction of several new restorative techniques, the dental structure can receive different sorts of surface treatment. The chemical priming of dental enamel, for instance, can be performed with other chemical agents such as nitric, maleic and pyruvic acids ${ }^{2,3,10,21,23}$, as well as with phosphoric acid. Dental enamel can also be subjected to mechanical treatments such as the aluminum oxide jet t $^{1,5,6}$.

* MSD, Department of Restorative Dentistry; ** PHD, Professor, Department of Dental Materials and Prosthesis; *** PHD, Professor, Department of Restorative Dentistry; ${ }^{* * * *}$ Full Professor, Department of Restorative Dentistry - School of Dentistry of Ribeirão Preto, University of São Paulo, Ribeirão Preto, São Paulo, Brazil. 
SILVA, P. C. G.; GONÇALVES, M.; NONAKA, T.; VINHA, D. Dental enamel: qualitative evaluation of the surface after application of aluminum oxide (microetching) using the scanning electron microscope. Pesqui Odontol Bras, v. 14, n. 4, p. 334-339, out./dez. 2000.

The use of aluminum oxide flow at high speed in order to remove dental structure had already been described by BLACK ${ }^{4}$ in 1945 . Cavity preparation was, at that time, performed with handpieces which worked at lower speeds than the handpieces used nowadays. That equipment produced heat, vibration and noise, which created relevant discomfort to patients. The initial suggestion of using abrasion with aluminum oxide was strengthened, aiming to diminish or even solve such inconveniences.

In 1951, one of the most prominent manufacturers of dental equipment, SS White, commercialized Airdent as the first unit of abrasive air. In order to use it correctly, interested professionals had to undergo intensive training. However, although air abrasion showed efficiency in cutting hard dental structure, such as dentin and enamel, it did not show the same efficiency in conforming the angles required by the restorative materials used at that time. Amalgam, gold and silicate cement were the only restorative materials prescribed for all classical Black preparations, which demanded defined angles and mechanical retention among other characteristics. Furthermore, the cost of the Airdent unit associated with the introduction of high rotation and micromotors, which were less expensive, inhibited its use for a long period. The idea of a flow of particles at high speed persisted and it was once again introduced as a prophylaxis technique with sodium bicarbonate in the mid 1980 's,12,19,22. Simultaneously, laboratorial procedures included the use of aluminum jet in the cleansing of inner surfaces of metal castings.

Nowadays, with the development of new abrasive air equipment, the procedure of microabrasion has been combined with several adhesive restorative techniques in the preparation of dental surfaces and of internal surfaces of indirect restorations, which will receive the application of adhesive materials. Its aim is to obtain residue-free surfaces with increased surface energy, improving the wetting capacity of the adhesive agents. Aluminum oxide jet has been used in procedures such as the initial preparation of dental surfaces before adhesive cementation, treatment of the metal surfaces of adhesive prosthesis, veener re-cementation (regarding dental structure as well as metal crowns), composite repairs, amalgam repairs, porcelain repairs, orthodontic band cementation, bracket bonding, crown cementation, inlay and onlay cemen- tation, dental pigment removal and cleft sealing, among others $\mathrm{s}^{8,11,13,14,15,16,17,18,24}$.

However, literature regarding the use of aluminum oxide jet is still rare as far as the alterations produced in the dental structure are concerned. Due to the increasing use of this resource in surface preparation for adhesion, the aim of this study is the assessment of the alterations produced by the use of abrasive air on dental enamel by means of scanning electron microscopy, considering the surface micromorphological changes.

\section{MATERIAL AND METHODS}

According to the aims of this study, dental enamel surfaces were subjected to mechanical priming with aluminum oxide jet and then observed by means of scanning electron microscopy.

Twenty third human molars extracted after eruption and stored in $0.1 \%$ aqueous timol solution were selected. All teeth were washed in running water for at least 12 (twelve) hours before the mechanical priming. This was carried out in the center of the vestibular surfaces of the teeth, in a $5 \mathrm{~mm}^{2}$ rectangular area. Micro Etcher II (manufactured by Danville Engineering Inc., USA), with $50 \mu \mathrm{m}$ particles, was the equipment used. The jet pressure was controlled by a manometer, connected to the compressed air tubing to which the equipment was connected, and it was kept at 80 psi.

The sampling group of 20 surface preparations was divided into 4 experimental groups, which received the following treatment variations:

- Group I: 10-second jet application, at a distance of $5 \mathrm{~mm}$, with $90^{\circ}$ of application inclination; 10-second air/water spray washing and, finally, air spray drying until the loss of brightness of the enamel surface;

- Group II: similar to Group I, varying only the angle of application to $45^{\circ}$;

- Group III: 15-second jet application, at a distance of $5 \mathrm{~mm}$, with $90^{\circ}$ of application inclination; 10-second air/water spray washing and, finally, air spray drying until the loss of brightness of the enamel surface;

- Group IV: similar to Group III, varying only the application angle to $45^{\circ}$.

After drying, all surface preparations, were kept at room temperature until their assembling on the microscope sample holders, metalization (Denton Vaccum - Desk II) and scanning electron microscopic observation (JSM 5410 of JEOL, Japan). 
SILVA, P. C. G.; GONÇALVES, M.; NONAKA, T.; VINHA, D. Dental enamel: qualitative evaluation of the surface after application of aluminum oxide (microetching) using the scanning electron microscope. Pesqui Odontol Bras, v. 14, n. 4, p. 334-339, out./dez. 2000.

\section{RESULTS AND DISCUSSION}

The observation of the surface alterations produced by aluminum oxide jet on the enamel of the vestibular surfaces of third upper molars, was recorded for each of the 20 (twenty) samples as follows: each sample represented by a rectangular area was divided into 4 quadrants; each quadrant had its middle area photographed; in addition, another photomicrograph was taken of the center of the whole sample. So, for each sample, 5 (five) photomicrographs were taken, totalizing 25 (twenty-five) records for each experimental group. In this phase, the visual analysis of each group was carried out, highlighting the most frequent features of each one of them.

In general, all groups exhibited irregularities, indentations and surface depressions with linear shapes, showing the pattern of the impact of irre- gular particles, applied under high speed flow and high intensity, on the dental enamel:

- Group I: surface randomly engraved, with lots of irregularities, showing the "collision" of aluminum oxide with it. The enamel prism structure is not revealed through preferential attrition (wear) of the head or the body of the prisms, such as it is under the effect of acid conditioning;

- Group II: aspects similar to Group I, showing smaller depths of indentation on the enamel surface;

- Group III: very irregular enamel surface, also showing high depths of indentation like Group $\mathrm{I}$, but in a more intense way in relation to Groups I and II;

- Group IV: enamel surface very altered, irregular, deeply marked, but with less deep indentations if compared with Groups I, II and III.
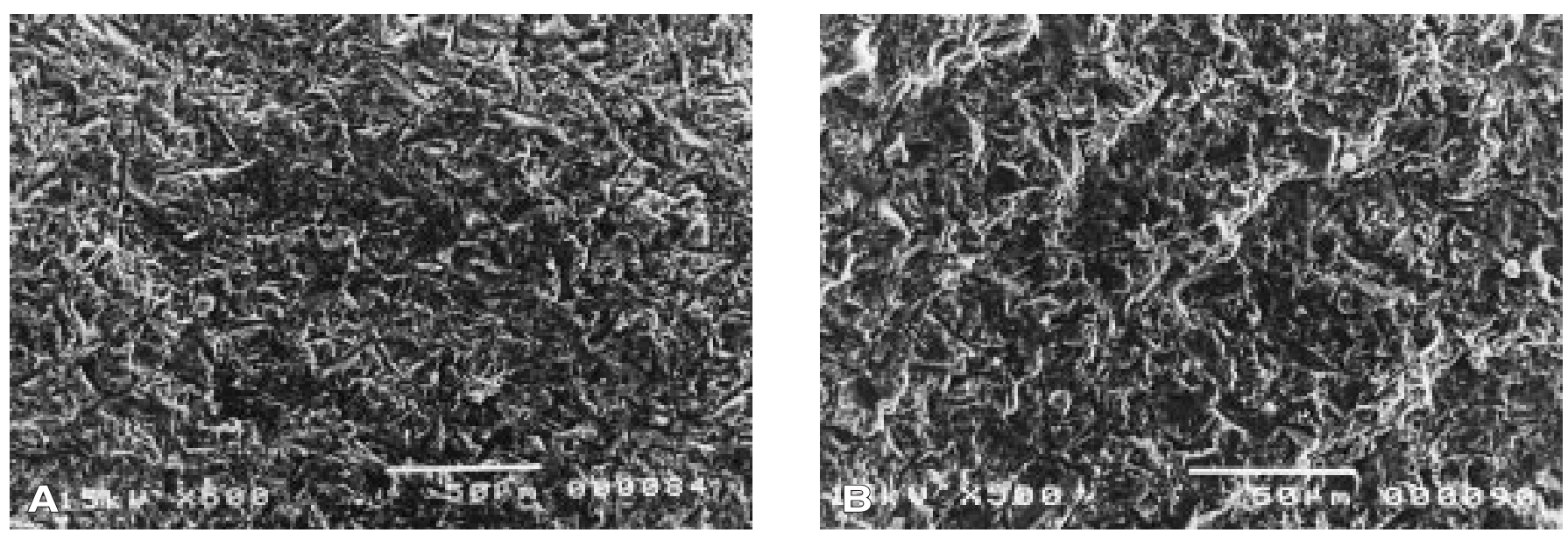

FIGURE 1 - Photomicrographic aspects of Group I (A) and Group II (B) (Original magnification: 500 X).
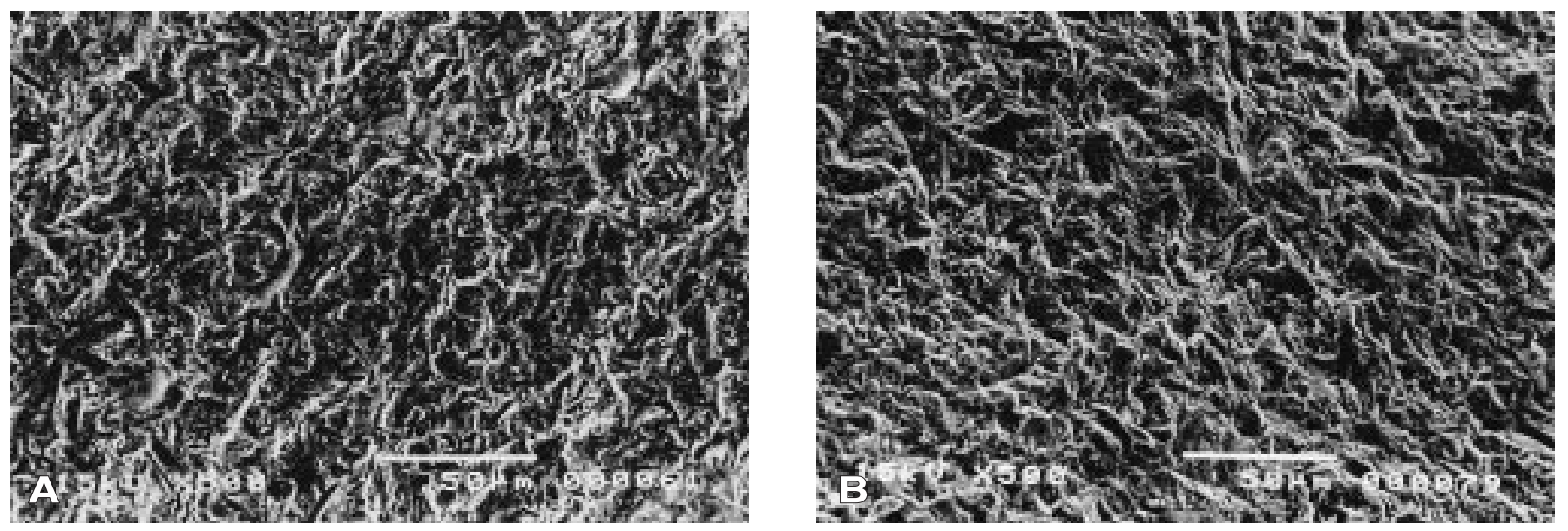

FIGURE 2 - Photomicrographic aspects of Group III (A) and Group IV (B) (Original magnification: 500 X). 
SILVA, P. C. G.; GONÇALVES, M.; NONAKA, T.; VINHA, D. Dental enamel: qualitative evaluation of the surface after application of aluminum oxide (microetching) using the scanning electron microscope. Pesqui Odontol Bras, v. 14, n. 4, p. 334-339, out./dez. 2000.
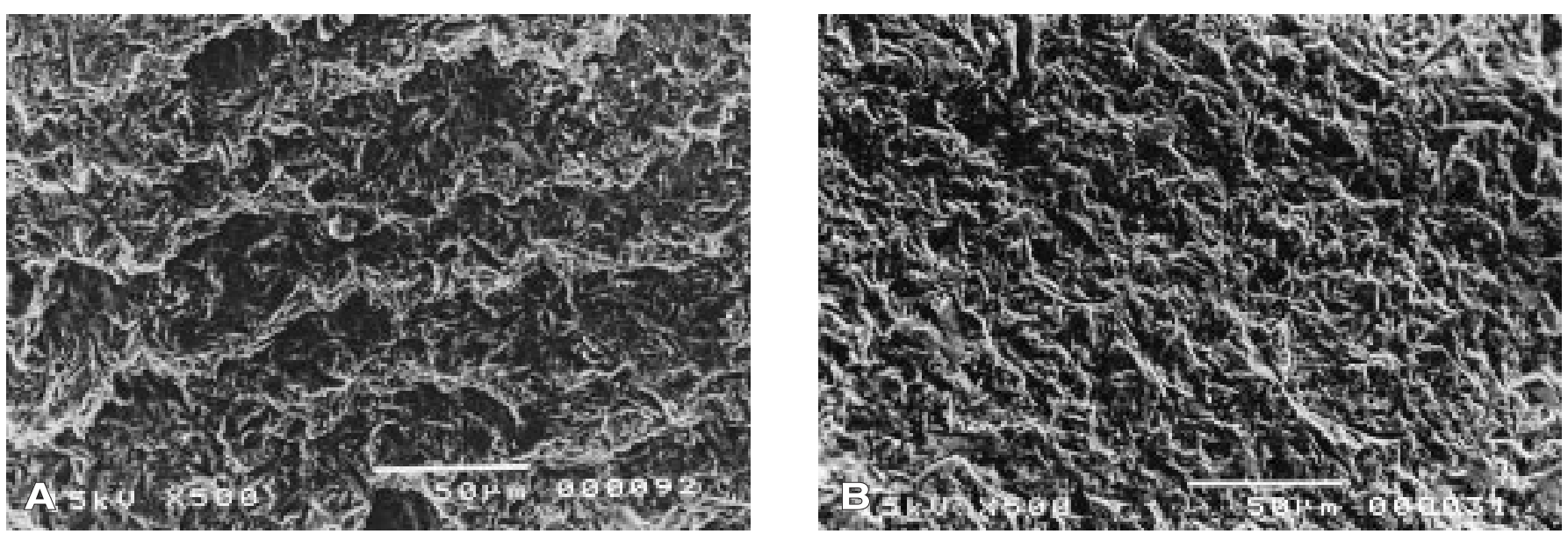

FIGURE 3 - "Fish flake" aspect showed by enamel after aluminum oxide jet application (A and B) (Original magnification: $500 \mathrm{X})$.

Figures 1 and 2 present aspects of Groups I, II, III and IV. The photomicrographs were carefully selected to illustrate the descriptions previously carried out for each group, since each group had 25 (twenty-five) photomicrographs taken of 5 (five) treated surfaces.

Besides the features mentioned above, eventual waves were observed on the enamel, which resembled fish flakes if observed slightly out of focus (Figure 3). In accordance with the purpose of this research, its simple aim has been achieved. Its importance is based on the fact that alternative chemical and/or mechanical surface treatments could be introduced in surface priming, including enamel priming. The presented results showed that the mechanical treatment of a highly organized tissue such as the enamel was not able to reveal the prism surface. With chemical treatment, which is selective, it is possible to reveal the organized prism surface as reported by SILVERSTONE et $a .^{20}$ in 1975 . The changes caused by microetching on the enamel surface are more qualitatively intense when aluminum oxide jet is used for 15 seconds at a 90-degree inclination. From this study on, chemical, mechanical and bonding resistance tests should be carried out on these new surfaces created by aluminum oxide treatment.

Although we do not know all of the new equipment, materials and techniques rapidly introduced by merchandising, air abrasion has been currently used, directly or indirectly, in our daily clinical practice.

\section{CONCLUSIONS}

The treatment of enamel surface with aluminum oxide jet created a new irregular superficial aspect, showing surface depressions which result from the impact of the particles, with linear shapes caused by high speed flow and high intensity. In this study, the most qualitatively intensive results were revealed when aluminum oxide jet was used for 15 seconds at a 90-degree inclination.

\section{ACKNOWLEDGMENTS}

This work was accomplished in the laboratory of electronic microscopy at Jaboticabal (Unesp, São Paulo, Brazil), with the collaboration of Prof. Dr. Jaime Maia Santos (Department of Nematology) and the support of Claudia Aparecida Rodrigues. 
SILVA, P. C. G.; GONÇALVES, M.; NONAKA, T.; VINHA, D. Dental enamel: qualitative evaluation of the surface after application of aluminum oxide (microetching) using the scanning electron microscope. Pesqui Odontol Bras, v. 14, n. 4, p. 334-339, out./dez. 2000.

SILVA, P. C. G.; GONÇALVES, M.; NONAKA, T.; VINHA, D. Esmalte dental: avaliação qualitativa da superfície tratada com jato de óxido de alumínio ("microetching") por meio de microscopia eletrônica de varredura. Pesqui Odontol Bras, v. 14, n. 4, p. 334-339, out./dez. 2000.

A Odontologia de nossos tempos conta com inúmeros recursos para o tratamento de pacientes. Com o desenvolvimento dos materiais adesivos e a introdução de novas técnicas restauradoras, a estrutura dental pode receber diferentes tipos de tratamentos superficiais. O uso do fluxo de óxido de alumínio em alta velocidade para a remoção de estrutura dental foi descrito por Black em 1945, no entanto, a literatura pertinente ao uso do jato de óxido de alumínio ainda permanece escassa no que se refere às alterações produzidas na estrutura dental. Atualmente, com o desenvolvimento de novos equipamentos de ar abrasivo, o procedimento de microabrasão vem sendo incorporado a várias técnicas restauradoras adesivas no preparo de superficies dentais e superfícies internas de restaurações indiretas, as quais receberão a aplicação de materiais adesivos. O objetivo simples deste estudo foi avaliar as alterações produzidas pelo uso do ar abrasivo sobre o esmalte dental por meio de microscopia eletrônica de varredura, observando-se as alterações micromorfológicas superficiais. A importância deste estudo baseia-se no fato de que tratamentos superficiais alternativos químicos e mecânicos venham a ser introduzidos para o condicionamento de superficies, inclusive do esmalte dental.

UNITERMOS: Esmalte dentário; Óxido de alumínio; Microscopia eletrônica de varredura.

\section{BIBLIOGRAPHIC REFERENCES}

1. ARAÚJO, M. A. J.; RODE, S. M.; VILlELA, L. C. et al. Avaliação qualitativa do efeito de agentes de limpeza na lama dentinária: estudo ultra-estrutural em microscopia eletrônica de varredura. Rev Odontol Univ São Paulo, v. 12, n. 2, p. 99-104, abr./jun. 1998.

2. ASMUSSEN, E., ARAÜJO, P. A.; PEUTZFELDT, A. In vitro bonding of resins to enamel and dentin: an update. Trans Acad Dent Mater, v. 2, p. 36, 1989.

3. BERRY, T. G.; BARGUI, N.; KNIGHT, G.T. et al. Effectiveness of nitric-NPG as a priming agent for enamel. Am I Dent, v. 3, p. 59, 1990.

4. BLACK, R. Technique for non-mechanical preparation of cavities and prophylaxis. J Am Dent Assoc, v. 32, n. 1, Aug. 1945.

5. BOYDE, A. Airpolishing effects on enamel, dentine, cement and bone. Brit Dent J, v. 156, n. 21, p. 287-291, Apr. 1984.

6. BROCKMANN, S. L.; SCOTT, R. L.; EICK, J. D. A scanning electron microscopic study of the effect of air polishing on the enamel-sealant surface. Quintessence Int, v. 21, n. 3, p. 201-206, Mar. 1990.

7. BUONOCORE, M. G. A simple method of increasing the adhesion of acrylic filling materials to enamel surfaces. $\mathbf{J}$ Dent Res, v. 34, n. 6, p. 849-853, Dec. 1955.

8. DIAZ-ARNOLD, A. M.; WILLIAMS, V. D.; AQUILINO, S. A. Tensile strengths of three luting agents for adhesion fixed partial dentures. Int J Prosthodont, v. 2, p. 115-122, 1989.

9. GERBO, L. R.; LACEFIELD, W. R.; BARNES, C. M.; RUSSEL, C. M. Enamel roughness after air-powder polishing. Am J Dent, v. 6, n. 2, p. 96-98, Apr. 1993.

10. GLASSPOOLE, E. A.; ERICKSON, R. L. The effect of various acids on enamel: determination, SEM, and bond strength. J Dent Res, v. 73, p. 387, Ab. 2281, 1994.

11. GOLDSTEIN, R. E.; WHITE, S. N. Intraoral esthetic repair of dental restorations. Esthet Dent, v. 7, n. 5, p. 219-227, 1995.

12. GONÇALVES, R. J.; MAZZONETO, S. F. Estudo comparativo entre os efeitos das técnicas de profilaxia com o Profident e a taça de borracha sobre o acúmulo de placa bacteriana. Rev Paul Odontol, v. 9, n. 3, p. 34-39, maio/jun. 1987.

13. KUPIEC, K. A.; WUERTZ, K. M.; BARKMEIER, W. W.; WILWERDING, T. M. Evaluation of porcelain surface treatments and agents for composite-to-porcelain repair. J Prosthet Dent, v. 76, n. 2, p. 119-124, Aug. 1996.

14. MADJAR, D.; DIVON-KUPERSHMIDT. Resin-bonded cast coverage for fractured posterior teeth. J Prosthet Dent, v. 68, n. 1, p. 15-18, July 1992.

15. McCAUGHEY, A. D. Sandblasting and tin-plating - surface treatments to improve bonding with resin cements. Rest Dent, Dental Uptade, $20^{\text {th }}$ Anniversary Issue, p. 153-157, 1993.

16. McINTYRE, F. M. Microetching the post space before luting post core. J Prosthet Dent, v. 73, p. 105, 1995.

17. MONDELLI, J.; PINHEIRO, R. F.; LANZA, L. D. Polimento de restaurações com amálgama: uma técnica alternativa utilizando jato de óxido de alumínio. Rev Odontol Univ São Paulo, v. 12, n. 4., p. 343-347, out./dez. 1988.

18. PAMEIJER, C. H.; LOUW, N. P.; FISCHER, D. Repairing fractured porcelain: how surface preparation affects shear force resistance. J Am Dent Assoc, v. 127, p. 203-209, Feb. 1996.

19. SAAD, J. R. C.; ANDRADE, M. F.; FONTANA, U. F. et al. Avaliação geral da utilização clínica do jato de bicarbonato de sódio. Odont Mod, v. 19, n. 2, p. 14-16, mar./abr. 1992.

20. SILVERSTONE, L. M.; SAXTON, C. A.; DOGON, I. L. et al. Variation in the pattern of acid etching of human dental enamel examined by scanning electron microscopy. Car Res, v. 9, p. 373-387, 1975 
SILVA, P. C. G.; GONÇALVES, M.; NONAKA, T.; VINHA, D. Dental enamel: qualitative evaluation of the surface after application of aluminum oxide (microetching) using the scanning electron microscope. Pesqui Odontol Bras, v. 14, n. 4, p. 334-339, out./dez. 2000.

21. SWIFT, E. J.; PERDIGAO, J.; HEYMANN H. O. Bonding to enamel and dentin: a brief history and state of the art, 1995. Quintessence Int, v. 26, p. 95, 1995.

22. WILlMANN, D. E.; NORLING, B. K.; JONHSON, W. N. A new prophylaxis instrument: effect on enamel alterations. J Am Dent Assoc, v. 101, n. 6, p. 923-925, Dec. 1980.
23. VAN MEERBEEK, B.; VANHERLE, G.; LAMBRECHTS, P. et al. Dentin and enamel-bonding agents. Curr Opin Dent, v. 2, p. 117, 1992.

24. VERZIJDEN, C. W. G. J. M.; CREUGERS, N. H. J.; VAN'T HOF, M. A. A multi-practice clinical study on posterior resin-bonded bridges: a 2.5-year interim report. J Dent Res, v. 73, n. 2, p. 529-535, 1994.

Recebido para publicação em 16/10/99 Enviado para reformulação em 09/05/00 Aceito para publicação em 22/08/00 